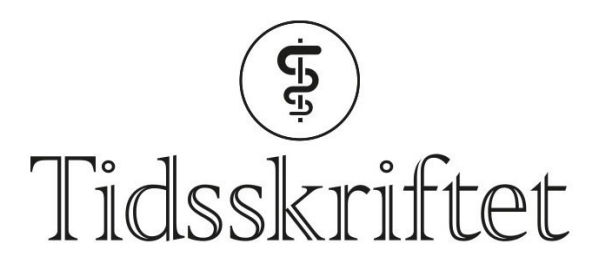

DEN NORSKE LEGEFORENING

\title{
Truende skyer over fremtiden
}

TIDLIGERE I TIDSSKRIFTET

SYNNE LOFSTAD

E-post: synne.lofstad@hotmail.com

Redaksjonssjef i Æsculap

I 1950- og 6o-årene ble det diskutert mulighet for utplassering av amerikanske atomvåpen i Norge, men det endte til slutt med et norsk nei. I 196o advarer Æsculaps redaktør Svenn M. Syversen mot gradvis tilvenning til den typen våpen, og er oppgitt over egne medstudenter (Æsculap 1960; 40: 49-50).

\section{Fredsvilje og atomvåpen.}

Kjære leser, kan du og jeg gjøre noe for å påvirke den politiske, militære og sosiale utviklingen i Norge og verden forøvrig. Nei, sier du og stapper nevene ned i bukselommene, politikken er for politikerne, militærvesen er for de militære eksperter, mens Nordisk lærebok i kirurgi er for meg, og det er gudhjelpe meg mer enn nok.

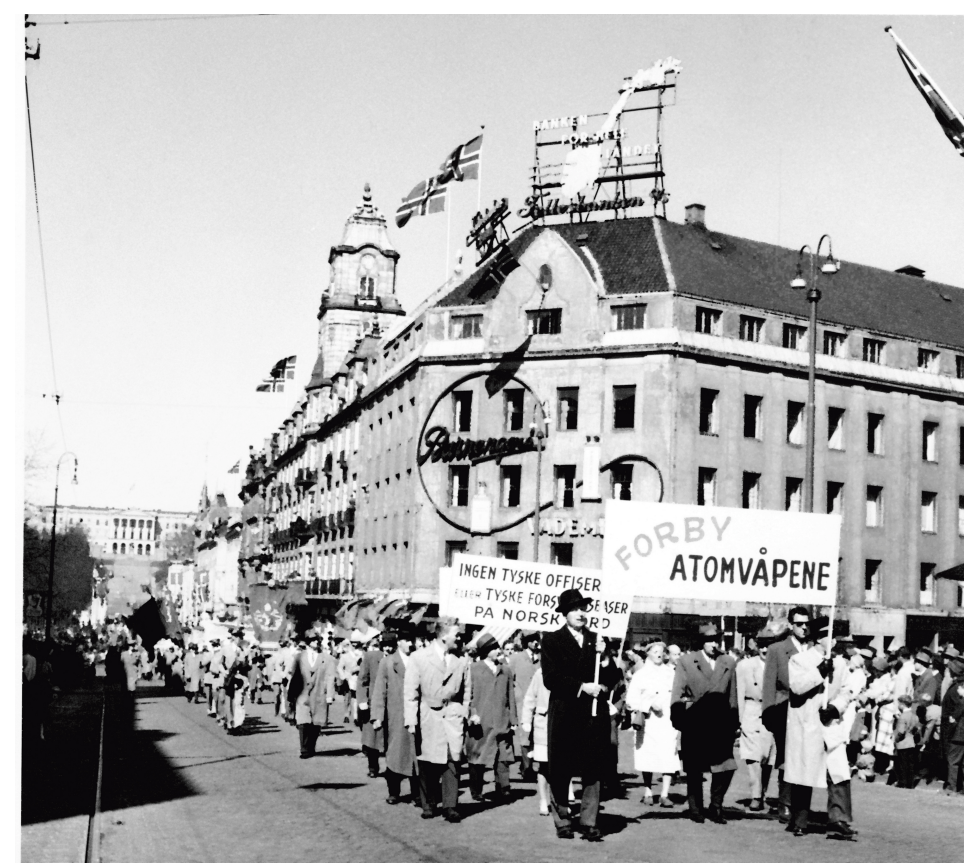

Første mai markeres for 70. gang med demonstrasjonstog og paroler i 1960 . Her toget på vei opp Karl Johans gate med parolen «Nei til Atomvåpen». Foto: NTB Scanpix

Men så lett slipper du ikke unna. Har du for eksempel hørt at det er på tale å stasjonere atomvåpen her i landet? Det har du altså. Hva er din mening i denne saken? Har du ikke gjort deg opp noen mening ennå. Godt hermed dikterer jeg deg hva du skal mene. Du skal 
mene at atomvåpen her i landet vil være en uting, en ulykke for oss som lever her og som gjerne vil leve i fred ennå noen år og som gjerne så at våre barn kunne gjøre det samme. Og ikke bare du alene skal ha denne mening, men du skal gjøre ditt til at andre også får denne mening og du skal rope ditt standpunkt ut til den likegyldige hop og til de blinde militarister.

Hvor mange medisinere var det som stilte i Studentersamfunnet da man behandlet spørsmålet om atomvåpen til Norge? I hvert fall ikke mer enn 5 og beklagelig nok var det minst 2 av disse som stemte mot resolusjonen som ble vedtatt og som hadde følgende ordlyd:

«Det Norske Studentersamfunn samlet til møte 19.3. 6 o tar skarpt avstand fra tanken om plasering av atomvåpen i Norge.

Et hvert skritt for å få flere land med atomvåpen i forsvaret innebærer en tilskjerping av den kalde krigen og minker dermed sjansene for en nedrustning.»

Du skal mene at atomvåpen her i landet vil være en uting

Ikke mer enn vel 100 studenter avga stemme, derav var ca. 2/3 for resolusjonen. La oss ikke håpe at dette er et tegn på at studentene stiller seg likegyldige til saken. Det ville være for deprimerende. (...)

Det ble hevdet at vi ikke skulle la følelsene tale, men lytte til fornuftige argumenteringer. Nei. Her skal ikke argumenteres. Atomvåpen står i dag for oss som en forferdelig ting, men hvis vi bare får drevet og argumentert lenge nok så vil vi venne oss til tanken om atomvåpen og de vil ikke lenger virke så avskrekkende. Og når de ikke lenger er så avskrekkende vil de også lettere kunne tas i bruk. Men atomvåpen er avskrekkende og det må de for alle menneskelige verdiers skyld fortsette å være. (...)

Hvorfor skal vi bruke all vår tid på å forberede oss på en kommende krig? Det skal være den eneste måte å unngå den på, heter det. Tror noen virkelig det? Det er visst ingen som forbereder seg på en kommende fred. Riktignok hører man stadig om fredsforhandlinger, men på samme tid rustes det som aldri før. Det er lite trolig at det skal komme noe særlig positivt ut av slike forhandlinger så lenge noen ikke har vilje til å ofre noe som helst, men derimot setter alt inn på å så sterkt militært rustet før forhandlingene at man kan kreve mest mulig. Gad tro om ikke også forhandlerne selv ville bli svært overrasket om det plutselig en dag skulle vise seg at forhandlingene virkelig førte til resultater.

Det er visst ingen som forbereder seg på en kommende fred

Hvorfor er situasjonen slik som den er med ganske truende skyer over fremtiden. Skal man tro at et flertall av verdens befolkning er enig i og gir sin tilslutning til den utviklingen som har foregått siden siste krig. Jeg kan ikke tro det. (...) Menneskene er for forsiktige med å la sin mening komme til uttrykk. De tror at de ikke har noe greie på utvikling og slikt og at det er andre som kan greie biffen så meget bedre. Ikke er det noen som spør så særlig mye etter deres mening heller.

Her er vår oppgave når det gjelder å påvirke utviklingen. For det første skal vi mene selv og la meningen komme til uttrykk. Dernest skal vi få andre til å mene og la sin mening komme til uttrykk. Vi må utvikle en sterkere vilje til fred. En vilje som er så sterk at den kan tillate oss å ofte ganske meget, umåtelig meget på fredens alter.

Mitt ønske er at fredsviljen kunne tillate oss å ofre så meget at vi ga alt militærvesen på båten. Vi kunne legge hele landet åpent som en demilitarisert øy i et hav av kanoner og raketter. Og så skulle vi vente og se. Vi ville satse 3,5 millioner mennesker på en usikker hånd. Men potten ville være varig fred. (...) 
(ㅇ) Tidsskrift for Den norske legeforening 2020. Lastet ned fra tidsskriftet.no 